\title{
Environmental Pollution and Management
}

\author{
Abu Mokeram Khondaker
}

\begin{abstract}
The ratio of doctors to patients is not in a balanced stage in Bangladesh. Newborns suffer from various diseases as a consequence of unplanned development, pollution \& lack of consciousness like Dengue, Diarrhoea, Viral fever etc. The marginalized community is suffering because of lack basic cleanliness education. The people of Bangladesh are paying a lot for health related problems. Apart from gene or genetic matters, diseases occur either as a consequence of environmental issues or lack of consciousness towards them. Sustainable pollution free environment and conscious citizen from all walks of life could cure $\&$ reduce diseases through a preventive way. Awareness may serve as a short-term remedy but sustaining it demands long time guidelines. Prevention is better than cure keeping this slogan in mind Treatment Included Prevention Services (TIPS) can keep vital role to mitigate the pollutions and diseases. TIPS is necessary for a sustainable community where diseases and pollutions wouldn't play its toll continuously. TIPS is a health treatment center where patient or doctor is not affiliated the same way as in a clinic or hospital. The core mission of the center is to develop a sustainable and conscious community \& environment where the rate of health related diseases would reduce gradually in a given time frame. Treatment unit and Study Circle (SC) unit will work together in a center. Study Circle on Environment and Health is a project carried out by the Association for Environment and Human Resource Development (AFEAHRD). The objectives of Study Circle on Environment and Health is to identify the sources of Environmental Pollution, discussed the health issues people face as result of pollution, increase awareness on Environmental issues and associated health problems faced by the people, and finally discuss action and remedies to eliminate or reduce some of the problems.
\end{abstract}

Index Terms - Study circle (SC), treatment included prevention services (TIPS).

\section{INTRODUCTION}

\section{A. Methodology}

Bangladesh is a country of about 154.7 million [1] (2012) people occupying an area of 147,570 square kilometers. It is one of the most densely populated countries of the world. Growth of massive hazardous pollutant bodies worsening the situation day by day. No wonder available healthcare facilities are no-match to the rapidly increasing urbanites and people suffer a lot owing to the lack of basic sense of healthcare and cleanliness practices. Inhabitants face diseases arising from pollutions and lack of consciousness on healthcare practice. In some cases, it has been found that city dwellers are encountering basic health related problems because of their self-made causes. The impacts of all these

Manuscript received September 3, 2013; revised December 9, 2013.

Abu Mokeram Khondaker is with the Association for Environment and Human Resource Development (AFEAHRD) Company, Bangladesh (email: mokeram@dhaka.net). together are creating negative impact to our common health and community.

\section{B. Environment and Health Problem in Bangladesh}

The ratio of doctors to patients is not in a balanced stage in Bangladesh. Newborns are suffering from various diseases as a consequence of unplanned development, pollution and lack of consciousness, like Dengue, Diarrhoea, Viral fever etc. The marginalized community is suffering lack of basic cleanliness education. The people of Bangladesh are paying a lot for health related problems. Apart from gene or genetic matters, diseases occur either as a consequence of environmental issues or lack of consciousness towards them. Government of Bangladesh is expending a lot from the National Budget for health care sector but this health care only provides treatment, medicine or vaccination to prevent diseases which has both physical and economical losses. The matter of fact is that no one is concentrating to prevent environmental diseases which is floating in the society and attacking people in every inter bell.

Environmental degradation and depletion of natural resources are often observed in Bangladesh due to poverty, over-population and lack of awareness on the subject. It is manifested by deforestation, destruction of wetlands, depletion of soil nutrients etc. Natural calamities like floods, cyclones and tidal-bores also result in severe socioeconomic and environmental damage. Waterborne diseases such as cholera are a serious threat to public health in Bangladesh. Until the 1970s, many of Bangladesh's people became sick from drinking polluted water drawn from surface rivers. Aid agencies such as the United Nations Children's Fund (UNICEF) built shallow wells throughout the country to help provide a safe source of drinking water to Bangladesh's poor.

In the 1990s, however, it was discovered that many of these wells were contaminated by arsenic, a poison that occurs naturally in Bangladesh's alluvial soils [2].

\section{Why Pollution Management Is Necessary}

Pollution and climate change are the major challenges of the $21^{\text {st }}$ century. Due to environmental pollution, various types of waste generation, large scale use of toxic pesticides, global climate change, frequent occurrence of various disasters around the globe etc. are the major concern of today's world. It is essential to explore the knowledge of causes of global climate change and its impact on human health, agriculture, water resources, civilization, etc. and how to adapt to these impacts and how to mitigate them properly, how to manage the environment for the well being of the living beings.

\section{Way of Solution}

Sustainable pollution free environment and conscious 
citizen from all walks of life could cure and reduce diseases through a preventive way. Awareness may serve as a shortterm remedy but sustaining it demands long time guidelines. Prevention is better than cure keeping this slogan in mind Treatment Included Prevention Services (TIPS) can keep vital role to mitigate the pollutions and diseases. TIPS is necessary for a sustainable community where diseases and pollutions would not play its role continuously.

\section{E. What Is the 'TIPS'?}

TIPS is a health treatment center where patient or doctor is no taffiliated the same way as in a clinic or hospital. The core mission of the center is to develop a sustainable and conscious community and environment where the rate of health related diseases would reduce gradually in a given time frame. Treatment unit and Study Circle (SC) unit will work together in a center. Doctor will physically observe the patients and will give them treatment. SC organizers will organize the patients for the treatment and to participate in the SC who may have been suffering because of the environmental issues or lack of consciousness. Then facilitator of SC unit will sit together with the Doctor and organizers and will try to identify the prevention method on how to reduce such diseases next time? The proposed Center will try to identify the causes of the health related diseases, and go for remedial action through SC on Environment and Health.

\section{F. Study Circle Process}

SC is a small group democracy at work. Community participants from all walks of life agree to attend a number of SC sessions to discuss an issue of common concern. A $\mathrm{SC}$ is a peer-led discussion of 8-12 participants; each participant has an equal voice. An impartial facilitator who is not necessarily an expert of an issue leads the group. The facilitator poses some questions to stimulate the discussion and to keep the discussion focused. The SC is run in a spontaneous and friendly environment. SC is a widely practiced social mobilization program in the Nordic States, especially in countries like Sweden, Finland and Norway. This has given the formation of firm democratic governments in those countries. Basic democratic principles were followed in the implementation of the SC process. Prior to the initiation of discussion, participants of each group were given a booklet containing a brief scenario of the present condition / extent of pollution along with a handful of questions on types of current pollutions that are to be discussed so that it becomes easier for them to initiate discussion and to avert confusion.

\section{G. Objectives of the Study Circle on Environment and Health}

The objectives of Study Circle on Environment and Health is to identify the sources of Environmental Pollution, discussed the health issues people face as result of pollution, increase awareness on Environmental issues and associated health problems faced by the people, and finally discuss action and remedies to eliminate or reduce some of the problems. Five common issues of Environmental concern such as: a) Unplanned Urbanization, b) Air Pollution, c) Pollution related to non-disposal of waste, d) Noise
Pollution and e) Water Pollution may be selected as the topic of discussion of this SC program. First, the effects that are caused by those problems are sorted out followed by their causes and consequences on the health of individual as well as in general people. At the concluding stage, discussion takes place with a view to coming out with a handful of remedial actions.

\section{H. Response Pattern of the Study Circle Participants}

Other than discussion, the response pattern of the SC participants will come out in the form of finding out causes, consequences as well as indicating on the remedial steps that could be taken on each specific type of pollution. The order denotes from common to group specific. After the discussion session, the participants pointed out to the causes, consequences and some remedial actions that could be taken with a view to lower the pollution associated with it.

\section{How to Materialize the Problems?}

It is quite difficult for an individual to materialize the recommendations by own. With the recommendations at hand along with representative of each SC team and TIPS health unit approach to the policy makers at both regional as well as national level so that these are materialized if not all together but in phases. The hierarchy will be from the local ward commissioner to the Member of Parliament and Ministers of concerned ministries. Community involvements with the assistance from SC unit also keep a vital role to materialize the problems. Moreover, when any person could realize that the diseases attack him/her has come from the environmental pollutions than will take steps to reduce it.

\section{EXECUTIVE SUMMARY}

\section{A. Executive Summary}

Study Circle on Environment and Health is a project carried out by the Association for Environment and Human Resource Development (AFEAHRD) with the assistance from National Democratic Institute for International Affairs (NDI), Sweden International Development Authority (SIDA), The United States Agency for International Development (USAID) [3]. SC on Environment and Health initiated its first round activities from April 2003 and ended through a central meeting on October 2003. The followings are a brief description methodology and an evaluation. The outcome of the ten circles ended successfully with quite a handful of worthy recommendations, which has pointed out some causes and consequences of common pollution related health problems along with their probable remedial actions which has been placed before the policy makers. The organizer took responsibility to organizing the SC members, carrying out administrative as well as organizational activities and report writing. The facilitators make the SC discussion lively and maintain neutrality for the smooth completion of the process.

\section{B. Ground Rules for Discussion}

The ground rules confirmed the spontaneous and unhindered participation of each and every participant. Some salient features of ground rules were: Each has to be given equal opportunity to talk, opinion of others has to be 
respected, will listen attentively to what others say, we will learn from each other and will wait for my turn to talk. Some of the house rules of the SC were: To arrival on time, give scope to others, will avoid side talk, cooperate with the facilitator, be an attentive listener, turn off the mobile phone and will not interfere while other talks. To make all these things work well. Facilitators were also trained to discourage discussion of irrelevant issues. The participants appreciated rules like raising hand before making questions, non-interference while another participant is talking.

\section{Common Platform of Discussion and Activities Other than Discussion}

Each of the groups was given some common questions to initiate discussion. They were given an informative booklet with the following topics: 1) Unplanned Urbanization 2) Solid Waste Pollution 3) Air Pollution 4) Sound Pollution and 5) Water Pollution. In addition to this, also provided them an Annex comprised of Environmental laws and affiliated newspaper clippings. The numbers of participants of the circles were between 10 and 12. Each circle discussion ran for 5 days with 2 hours discussion time. The purpose of the SC was to take initiative in a peaceful and democratic way in order to protect the Environment in general and health in particular.

\section{How Compiled the Discussion}

Discussion pattern approached in three stages; finding causes, assessing consequences and placing forward recommendations. At the beginning of the discussion, the organizers and facilitators had to take notes from each and every SCs. After compiling those notes they handed it over to the coordinator for verification. Once the coordinator had gone through it; it was again given back to the representative committee to distribute it to the Group participants to check whether any crucial point is missing or not. Their feedback was re-compiled and was given the form of final report which has been presented at the Report Presentation and Discussion meeting.

\section{E. Representative Team}

The recommendation represents a well aware conscious civic group powered to raise their voice for effective change and development in public welfare. With the recommendations at hand, the team decided to approach the policy makers at both regional as well as national level so that these are materialized if not all together but in phases. The hierarchy will be from the local ward commissioner to the Member of Parliament and Ministers of concerned ministries. A core group works on it which named as Representatives Team with two participants from each of the SC groups. Other than sitting informally with people in different areas of Dhaka, This group will approach the policy maker with the recommendations. At the interim period between the closure $10 \mathrm{SC}$ groups and Report Presentation and Discussion Meeting, this group sat Five times for discussion with a view to materialize the recommendations. Organizing the Report Presentation and Discussion Meeting has been one of their grand successes (see Fig. 1).

The Representative Team approached (October 2003) to the Policy Makers, the following recommendations on five common environmental issues which came out from Study Circle discussions.

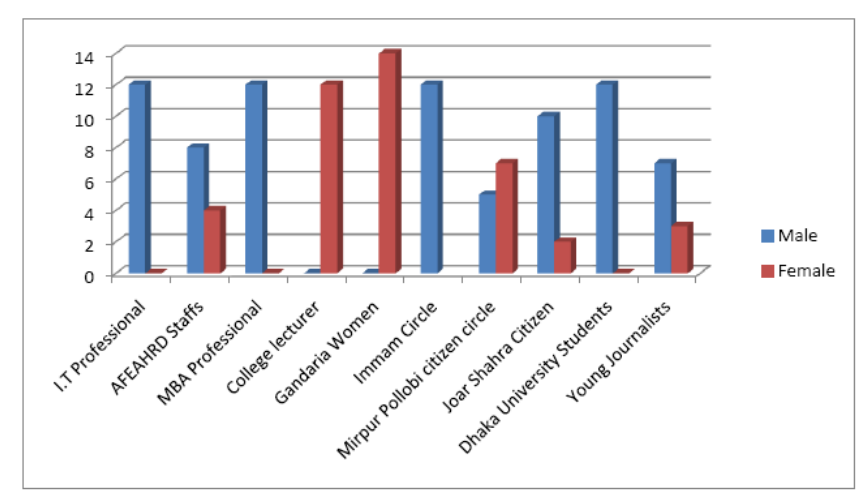

Fig. 1. Participants at a glance.

III. THE REPRESENTATIVE TEAM APPROACHED (OCTOBER 2003) TO THE POLICY MAKERS, THE FOLLOWING

RECOMMENDATIONS ON FIVE COMMON ENVIRONMENTAL ISSUES WHICH CAME OUT FROM STUDY CIRCLE DISCUSSIONS

\section{A. Unplanned Urbanization}

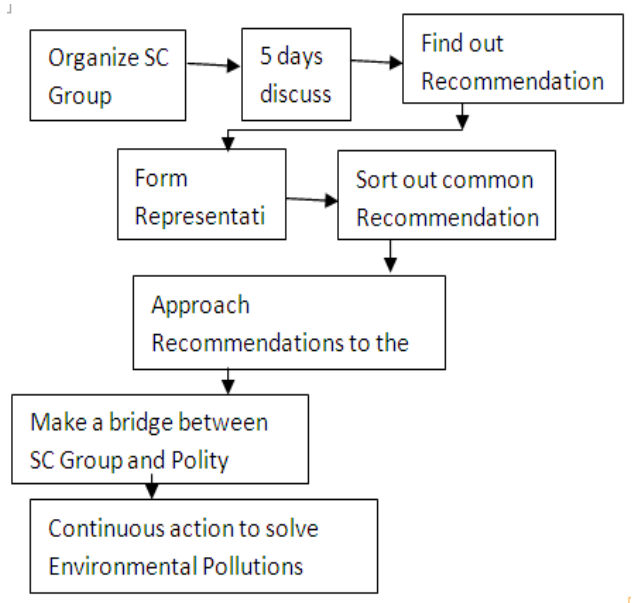

Fig. 2. SC Team members' role.

Inter-departmental coordination has to be maintained amongst water supply and sewerage authority, Electric supply authority, telephone and telegraph, gas connection authority. Administrative functions of greater Dhaka have to be decentralized. All commercial activities could be transferred to commercial capital Chittagong. Service delivered by the Government run city corporation could be assigned to private sectors. Play ground, parks, ponds, wetlands have to be maintained properly. These have been kept in consideration while developing new towns and cities. Industrial area, Commercial area, Residential area has to be setup in particular areas Houses have to be built as per approved design and there have to be ample open space around them while building. High-rise buildings have to be built with proper earthquake resisting mechanism. Community mobilization group could be formed with teachers, head of religious institutions and ward commissioners of municipal areas with view to gear up local area development. Laws have to be enforced strictly. This has to be complemented with the enforcement of 
Metropolitan court Act. Dhaka City Corporation and other related Ministries' employees have to be trained so that they deliver their service more efficiently. With a view to ease traffic congestion, diversion roads could be constructed and in special cases, some roads could be made one-way. Cities and towns have to be expanded to its out skirting areas. All types of illegal establishments including unauthorized slums have to be evacuated in order to implement planned development works. Laws have to be enforced properly and existing laws loop holes has to be amended (see Fig. 2).

\section{B. Solid Waste Pollution}

Waste should not be treated as waste but as asset. Waste could be turned into biogas and natural manure/compost. Instead of roadside dustbin, imitative could be taken to collect waste from each and every home. If roadside dustbins are to be kept, these have to be built using modern technique and with cover so that garbage does not spill over. Waste has to be disposed regularly and at night. Awareness has to be developed to separate Degradable; non-degradable and harmful waste at home.

\section{Medical Waste Pollution}

Medical waste could be destroyed inside the medical compound. If these are to be brought out of the compound, it has to be done using custom-made vehicle so that germs do not spread. Recyclable items like syringe, saline, bottle could be collected separately. Scientific and sustainable policy has to be adopted for waste disposal management. Under no circumstances, medical waste should be mixed with other waste. Number of public toilets has to be increased with adequate trained manpower for proper maintenance. Public toilet could be built at re-fueling stations with easy access for general mass. There could be separate toilet arrangement for women.

\section{Air Pollution}

Brick-kilns has to be re-allocated at a particular place far from the city. Chimneys have to be made taller and natural gas has to be used instead of firewood. Construction work of roads has to be carried out at night. Old vehicles have to be banned from playing the city streets. The following measures could be taken to ban smoking. Smoking in public places has to be banned. Higher taxes has to be imposed on cigarettes and materials used to manufacture them. Selling of smoking related items at public places has to be banned and such items must not to be sold to customers below a particular age limit. Advertising of smoking by popular models in theater, cinema halls or in any other mass media has to be banned. The Government could fix particular places for smokers. Insecticides to destroy flies, mosquitoes, could be used at a limited extent. Proper ventilation facilities have to be kept while building houses. Driver could be trained by the Bangladesh Road Transport Authority (BRTA) to prevent air pollution.

\section{E. Sound Pollution}

Law has to be enforced properly. Concern authority have to take strict measure so that decibel limit applicable to silent areas, residential areas, commercial areas, industrial areas, mixed areas are followed by individuals vehicles etc. Sound limit measuring machines has to be set up at different parts of the city so that it is monitored properly. Hydraulic horns have to be banned and the use of horns has to be kept within the acceptable decibel limit. High sound from defective vehicles could be checked by imposing laws. The use of mike in residential, silent areas, in front of schools, colleges and hospitals has to be banned. In the case of use for special purposes, the use has to be kept limited. The use of mike in metropolitan area has to be banned in areas other than specified by the municipal authority. The use has to be restricted only for campaign, meeting, procession etc. Mills and factories adjoining residential areas have to be reallocated in industrial areas far from residential areas. Activities like media campaign, formation of civic committees of campaigns could be carried out by heads of religious institutions in order to raise civic consciousness. Traffic system has to be modernized. Programs like training for both the traffic police and drivers, recruiting more traffic police and strict laws for traffic rule violations could be initiated.

\section{F. Water Pollution}

Connecting sewerage line to rivers has to be banned. If has no alternatives recycling system should be implemented. Sewerage line has to be arranged separately from water supply lines. These are to be maintained properly. Discharge connection for toxic produced in mills and factories has to be diverted to waste treatment plant instead of discharging those into rivers, canals etc. Illegal encroachment and structure from riverbanks has to be enforced to prevent such encroachment. A total enforcement of wetland law has to be enforced. Age old and defective vessels has to be removed. Strict sanction has to be imposed so that vessels do not discharge any toxic materials in the water bodies. In order to prevent water logging, water drainage lines has to be checked on timely basis and kept obstacle free. Dredging has to be done regularly so that rivers are kept nevigatable. Instead of utilization underground water, surface water could be recycled for everyday use. Rainwater could be preserved to meet the purpose. In the case of newly developed town, digging of ponds could be re-excavated. \# Sanction has to be imposed so that no body throws bodies of dead animals into river bodies.

\section{G. Recommendations Implementation Procedure}

The Representative Team approached the above recommendations to the policy makers on October 2003 together all SC participants at a seminar. After the completion of the seminar when the policy makers not willing to accomplish the recommendations then the SC team together took actions several times with a demonstration, seminar etc in a National level. The SC team also took initiative in their locality again and again to mitigate environmental pollution which had in their capacity. The whole program coordinated by the Representative team, Organizers and Facilitators together.

\section{TIPS REDUCED ENVIRONMENT POLLUTIONS IN THE COMMUNITY}

Dhaka was one of the most polluted city (2003) in the 
world. The citizens of Dhaka are now (2013) more conscious about their environmental rights. The Garbage collection system has been developed. Working together with other pro-environment bodies, several important successes have been achieved. Among these are introduction of unleaded gasoline, ban on two-stroke engine vehicles, ban on use of plastic bags, enactment of wetland protection law, formation of the river task force, formulation of new building rules, etc. [4] Moreover Detail Area Plan (DAP) has been formed in Dhaka city. The provision of DAP is inherent in the Structure Plan with some specific purposes. These are: a. Provide basic infrastructure and services in the study are through systematic planning. b. Create congenial environment to promote economic activities. c. Improve drainage system of the area and protect flood flow from encroachment. d. Create service centers to enable urban growth [5]. Besides Law and Order on Environmental issues has been strengthened in Bangladesh.

\section{TIPS FOR POLLUTION MANAGEMENT}

Study Circle on Environment and Health, the case study on Dhaka city in the year 2003 had been proved that pollution management possible through TIPS. Although, there are some pending recommendations to be solved but the policymakers has taken the initiative to solve the issues seriously. The positive impact is that gradually the pollution scenario has been changing in Dhaka city. General Citizen of the particular community has taken initiative in their locality to kick out the pollutions. They have realized most of their sufferings from diseases come only due to the degradation of environmental pollution. The policy makers also have taken prompt action to mitigate the pollution because of common approach of the society. TIPS, not only works on current pollution issues but also works on future pollutions through regular SC discussion unit. TIPS, is a sustainable pollution management program.

\section{CONCLUSION}

In sum up considering all the factors, TIPS can be a strong weapon to phase out pollutions in the community. It will ultimately effect the global environmental pollutions like climate change. People will develop through TIPS the sense of urgency to reduce the pollutions because they have understood that the most of the diseases they are suffering only due to the environmental pollutions. TIPS will ultimately develop the Quality Life Index (QLI).

\section{REFERENCES}

[1] Word Bank. (Sep. 8, 2013). On the use of searching public data or change visualization. [Online]. Available: http://www.google.com.bd/publicdata/explore?ds=d5bncppjof8f9_\& met $\mathrm{y}=\mathrm{sp}$ pop totl\&hl=en\&dl=en\&idim=country:BGD:PAK

[2] A. K. Singh, "Chemistry of arsenic in groundwater of GangesBrahmaputra river basin," Current Science, vol. 91, no. 5, pp. 599606, 2006.

[3] Association for Environment and Human Resource Development (AFEAHRD), Ministry of Social Welfare, Government of Bangladesh, Registration no- DHA-04162, June 25, 1998.

[4] Bangladesh Poribesh Andolon (BAPA). (2000). Bangladesh. [Online]. Available: http://www.bapa.org.bd

[5] Capital Development Authority of Bangladesh, Development Plan for Dhaka City, Bangladesh, December 2008.

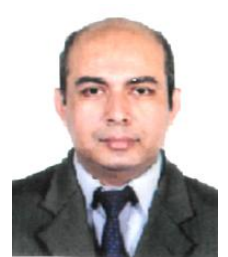

Abu Mokeram Khondaker was born on December 30, 1976. He got his master in business administration (MBA) from American International University-Bangladesh (AIUB), Dhaka, Bangladesh in February 2010. He got the bachelor of Commerce in accounting from National University-Dhaka, Bangladesh.

$\mathrm{He}$ is the executive director in association for environment and human resource development (AFEAHRD) Company. 